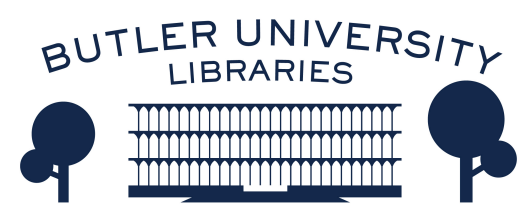

Journal of Hindu-Christian Studies

Volume 9

Article 16

January 1996

\title{
Book Review: "Swami Abhishiktananda: His Life Told Through His Letters"
}

Anand Amaladass

Follow this and additional works at: https://digitalcommons.butler.edu/jhcs

Part of the Religion Commons

\section{Recommended Citation}

Amaladass, Anand (1996) "Book Review: "Swami Abhishiktananda: His Life Told Through His Letters"," Journal of Hindu-Christian Studies: Vol. 9, Article 16.

Available at: https://doi.org/10.7825/2164-6279.1138

The Journal of Hindu-Christian Studies is a publication of the Society for Hindu-Christian Studies. The digital version is made available by Digital Commons @ Butler University. For questions about the Journal or the Society, please contact cbauman@butler.edu. For more information about Digital Commons @ Butler University, please contact digitalscholarship@butler.edu. 
these models. Sometimes one wonders whether the terminologies used by the thinker to convey the mystery that is expounded is adequately understood from the author's point of view. The language of the critique from the traditional position does not meet the challenge that is proposed. For instance, the cosmotheandric mystery that Panikkar talks about with reference to Phil.2.9 is dismissed as "exegetical machiavellism". The theocentric approach of Samartha, Puthiadam, and others are opposed to Christocentrism, and so on. One gets the impression that the loyalty to the traditional thinking and its formulation dominates the scene, leaving aside the mystery that is being contemplated. This is not necessarily loyalty to the faith in Jesus Christ but very often is a sign of inability to look beyond the traditional framework. Thus this approach does not highlight sufficiently the process brought about by the ferment of fresh thinking in the Indian Church.

Secondly, the whole discussion is presented as Asian contribution, but the tone and language are of the thinking within the
Christian traditions without sufficient reference to other religious traditions in Asia. Practice of dialogue has to grow yet to reach that level, because the dialogue is restricted to Christian thinkers from within their framework without sufficient exposure to the theologies of other religious communities. Such exposure would change the language. The author himself concludes that interreligious dialogue presupposes a theology of religion. And the field of the theology of religions is still greatly unexplored (p.394). In the concluding section the elements of the emerging theology of dialogue are summed up with its future prospects.

But this volume is well documented and is a helpful source to identify different thinkers who have written on dialogue. Any library will be eager to have a copy of it as ready reference on matters relating to the discussion on interreligious dialogue in India.

Anand Amaladass, S.J.

Madras

\section{Swami Abhishiktananda: His Life Told Through His Letters. James Stuart. Delhi: ISPCK, 1995, xvi+348 pp.}

THE BIOGRAPHY O.F Swami Abhishiktananda, the French monk Henri le Saux (1910-1973), is presented as an autobiography letting the man speak through his letters written to his friends. Abhishiktananda was in India for 25 years (1948-1973) trying to live up to an ideal, a mission he set for himself, to realize the truth of advaita, as he understood it to be the core of the Upanisads and the search of the Hindu saints. Remaining "viscerally" Christian, he explored the possibility of harmonizing Hindu and Christian experience.

Abhishiktananda is known to many through his books and some of them have been translated into different languages. The man behind these writings is revealed through this book. This was first published in 1989 and the revised version of it, which is now under, review, appeared in 1995. The volume is made possible by the many admirers who preserved his letters and shared their recollection of him. The author of this book has done a marvellous work in weaving together letters of this great man in such a way that the readers discover the man and his spiritual journey through these pages without even being aware of the biographer's presence.

Church history in India is recorded in and through personalities like 
Abhishiktananda. One could call it an experiment and evaluate its success and drawbacks. But Abhishiktananda remains as a dialogue between two traditions in his life. One cannot ignore an approach of this type in the Hindu-Christian encounter. Such "experiments" cannot be measured in terms of success or failure - and that could be said of the Christian presence in India in general or anywhere for that matter. The letters of Abhishiktananda reveal the struggles he underwent, his continuous search, his moments of enthusiasm and disappointment, and above all the seeking of the guidance of the Spirit. This book portrays the man as he was in his spiritual journey - his concern, his frustration, his perseverance in keeping the mission in sight; admitting his inadequacy, and so on.

It is not a theology that is to be judged in such an attempt. The process is more important than the product. Whether he achieved anything tangible is the wrong question to ask. The vibrant presence of such a pursuit is a value in itself. Those who look for such results are not the ones who understand the ashram ideal, the value of silence or of being a witness. The spirit behind such a pursuit is what inspires others. Abhishiktananda's diaries have such a lyrical charm that they attract the readers with spontaneity and freshness. His intellectual stamina to keep writing - to reflect, to articulate, to reformulate, summarize, etc., given the conditions in which he lived - is something admirable.

In the history of the Indian Church he occupies an important place - as one of the "Fathers of the Indian Church" - acting as a spiritual and theological ferment. In fact attempts are made to evaluate his Christology and his understanding of Christ from his writings. Abhishiktananda responds to such questions thus:

There is a message from India which must be passed on... But this message is not conveyed in words. Souls have to be opened up from within... There are people for whom the advaitin experience is an existential matter, and others for whom it is speculative and worse still, certain people identify it with the ideas of those who follow Guenon and other esotericists. So they do not understand the real problem. They argue and then pass sentence in the name of the faith, without really noticing that this experience is precisely summoning the faith to a great purification. (p.161)

Abhishiktananda is usually portrayed as a man of advaitic enlightenment. With all his search for the Absolute, he remained quite "earthy" - concerned about the poor who died of starvation and sickness. And this volume reveals the man Abhishiktananda. Those who have not seen him or read any of his writings will find this book quite valuable and those who are aware of his writings will discover in this book another dimension of Abhishiktananda.

Anand Amaladass, S.J. Madras

\section{Majesty and Meekness: A Comparative Study of Contrast and Harmony in the Concept of God. John B. Carman. Grand Rapids,} Michigan: William B. Berdmans Publishing Company, 1994, 453 pp., incl. glossary and index.

JOHN CARMAN HAS brought together in this book a wide variety of ideas from different religious traditions about the nature of the divine Reality. Acknowledging and 